Article

\title{
Study of a Large Square Baler with Innovative Technological Systems that Optimize the Baling Effectiveness
}

\author{
Arrigo Salvatore Guerrieri ${ }^{1}$, Alexandros Sotirios Anifantis ${ }^{2}$ (i), Francesco Santoro ${ }^{2}(\mathbb{D})$ \\ and Simone Pascuzzi ${ }^{2, *(D)}$ \\ 1 Department of Agriculture, Forests, Nature and Energy, University of Tuscia, Via San Camillo de Lellis snc, \\ 01100 Viterbo, Italy; guerrieriarrigo@yahoo.it \\ 2 Department of Agricultural and Environmental Science, University of Bari Aldo Moro, Via Amendola 165/A, \\ 70126 Bari, Italy; alexandrossotirios.anifantis@uniba.it (A.S.A.); francesco.santoro@uniba.it (F.S.) \\ * Correspondence: simone.pascuzzi@uniba.it; Tel./Fax: +39-0805442214
}

Received: 1 April 2019; Accepted: 24 April 2019; Published: 26 April 2019

\begin{abstract}
The employment of bales is of considerable interest in the agricultural sector due to the mechanization of the production chain, the ease of their manipulation and transport, the low requirements for, and flexibility of, their storage and the low manpower requirements. Forage bales are mainly employed in zootechny, which albeit with important changes, is today still an essential economic sector for our society. The optimization of results in the zootechnical field depends largely on the feeding of the animals; in this regard, fodder-crops play a fundamental role in the European agricultural and economic sector. The soil inside the fodder is often the vehicle for a large number of CFUs (colony forming units) of bacteria of the Clostridium genus, with consequent repercussions for the welfare of the cows as well as for the quality of the milk products. The purpose of this work was to assess the performance of the large square baler HD 1270, made by the Italian manufacturer "Cicoria Square Bales", whose main characteristic is the high cleanliness level of the dried fodder. The experimental tests carried out seem to confirm the efficacy of the technical solutions adopted for this machine. However, in order to better understand the reliability of the machine in lowering the amount of impurities and soil present in the built square bales, further tests in different working conditions should be carried out in order to statistically evaluate the influence and the mutual interaction of the operating parameters.
\end{abstract}

Keywords: square baler; hay; straw; biomass; soil inside bales

\section{Introduction}

The employment of bales is of considerable interest in the agricultural sector due to the mechanization of the production chain, the ease of their manipulation and transport, the low requirements for, and flexibility of, their storage, and the low manpower requirements [1]. Bales increase storage capacity, giving farmers greater long-term flexibility in feeding [2,3]; additionally, they can significantly reduce post-harvest biomass losses [4-6]. The meaningful use of straw bales is also seen in the construction sector where, being a natural material, bales may represent a good alternative to traditional thermo-acoustic insulators for sustainable buildings [7-10]. Hay bales are mainly employed in the zootechny, which albeit with important changes, is today still an essential economic sector for our society [2]. The optimization of results in the zootechnical field depends largely on the feeding of the animals; in this regard, fodder-crops play a fundamental role in the European agricultural and economic sector. The production of dried fodder has relevance in Southern 
Italy whereas silage fodder is used in Northern Italy due to the climatic-territorial characteristics [11]. The manufacturing of big bales comprises several mechanical treatments, ranging from harvesting to storage, to obtain high quality forage in terms of its nutritive value and hygiene characteristics. This takes into consideration that the drying of the forage is accompanied by a competing process of deterioration caused by the substantial development of the existing microflora, which causes the loss of nutrients and probably the production of toxic metabolic products [12].

The Haymaking is the most traditional system of plant conservation, having a relatively thin stem, based on a set of operations aimed at obtaining the elimination of the greater water content in freshly mown grass $[13,14]$. This technique is based on leaving mown fodder on the field until it reaches at least $80 \%$ dry substance. It is a burdensome system due to the considerable use of labor, the losses of dry substance and nutritional value that occur, in particular for leguminous crops [15]. Unfortunately, the agronomic and meteorological conditions generate physical and microbiological problems in the production of fodder in Central and Southern Italy. Some of the fundamental complications are: (i) the high content of clostridia; (ii) the presence of terricolous anaerobic bacteria; (iii) the high humidity rate held inside the bales of dried fodder. The soil inside the fodder often is the vehicle for a large number of CFUs (colony forming units) of bacteria of the Clostridium genus, with consequent repercussions for the welfare of the cows as well as for the quality of the milk products $[15,16]$.

The natural habitat of clostridia is in the soil and the amount in which they are present is affected by several parameters, such as the texture of the soil (skeleton-rich soils contain less spores), the quantity and quality of the organic fertilizers coming from zootechnical dejections, and so on. The spread of clostridia follows a definite pattern [15]:

- The spores contained in vegetable products dirtied with soil influence the number of spores present in the preserved alimony (dried fodder);

- The number of spores present in food affects the number present in the stools, which inevitably contaminate the rearing environment, the animals, the milking equipment and consequently the milk;

- The stools in turn, that come back to the soil as organic fertilizers, return the spores to the soil and may induce contamination phenomena.

The presence of soil in forage is, therefore, a negative factor, since the bacteria present in it can affect the functionality of the digestive system of cows, with negative effects also in the dairy sector, as it favors defects of late swelling inside cheeses that have medium and long preservation $[3,16]$.

Balers are machines that pick up loose hay or straw, compress it into bales of even size and weight and tie them by means of twine, carrying out these operations in compliance with the operators' safety requirements [17-20]. As is known, agriculture is one of the sectors of greatest risk, in terms of both the severity and frequency of injuries, and therefore particular attention is required to develop protective and preventive measures to protect agricultural operators' health and safety; above all, including the use of machines and equipment designed and built according to the safety laws in force [21-25]. The baler has also been studied with particular attention to the effects of whole-body vibrations experienced by tractor drivers [26]. Essentially, there are three types of balers on the market which produce: (i) small rectangular bales (weighing up to $25 \mathrm{~kg}$ in straw); (ii) big round bales (in the range of 245 to $400 \mathrm{~kg}$ in straw and 300 to $400 \mathrm{~kg}$ in hay); (iii) big square bales (in the range of 120 to $600 \mathrm{~kg}$ in straw and 200 to $900 \mathrm{~kg}$ in hay) [27]. Bearing the aforesaid in mind, the purpose of this work was to assess the performance of a large square baler, made by a manufacturer located in Southern Italy, whose main characteristic is the high cleanliness level of the dried fodder. The main construction and functional characteristics of this innovative machine are illustrated, and results of experimental tests concerning the amount of residual soil and impurities inside hay and straw bales made with this square baler, compared with results obtained from other similar machines, are reported. 


\section{Large Square Baler from “Cicoria Square Bales" Manufacturer}

The large square baler, HD 1270, is an innovative machine manufactured by "Cicoria Square Bales" (hereinafter "Cicoria's machine"), located in Palazzo San Gervasio (Potenza district, Southern Italy). Figure 1 shows a schematic working outline of the machine. The cardan shaft transmits the motion to a double-stage reduction gear (1) and via a rocker kinematic mechanism (5) to the rocking piston (6). The pick-up gatherer (2) collects the product and transfers it to the supply channel. The feeder system is formed by the feeder rotor (3) and the pre-compacting rotor (4). The feeder rotor moves the product from the pick-up to the pre-compacting rotor, which pushes the product in the compression chamber. The rocking piston (6) compresses the product in the compression chamber. The knotting devices (6) bind the six strings that keep the bale once this last reaches the required length. The hydraulic cylinder (8) acting on lateral and upper pressers determines the compacting level (Figure 1). Three high technology devices developed for the purpose of lowering the cost of wrapping and baling are the main features of Cicoria's machine: (i) the compression system; (ii) the feeding system from the top; and (iii) the binding system. Compression is carried out through a leveraged piston system, which transforms the circular movement of the big diameter flywheel into a curvilinear pattern for the piston to be able to apply a strength of about $1.8 \times 10^{5} \mathrm{~N}$ inside the baling chamber. This reliable fulcrum and balance device, providing greater fluidity, eliminates the piston's roller, guides and bearings in the baling chamber, so as to optimize baling performance. Furthermore, the leveraged piston system allows a reduced power requirement (less than $60 \mathrm{~kW}$ ) compared to the traditional longitudinal piston movement.

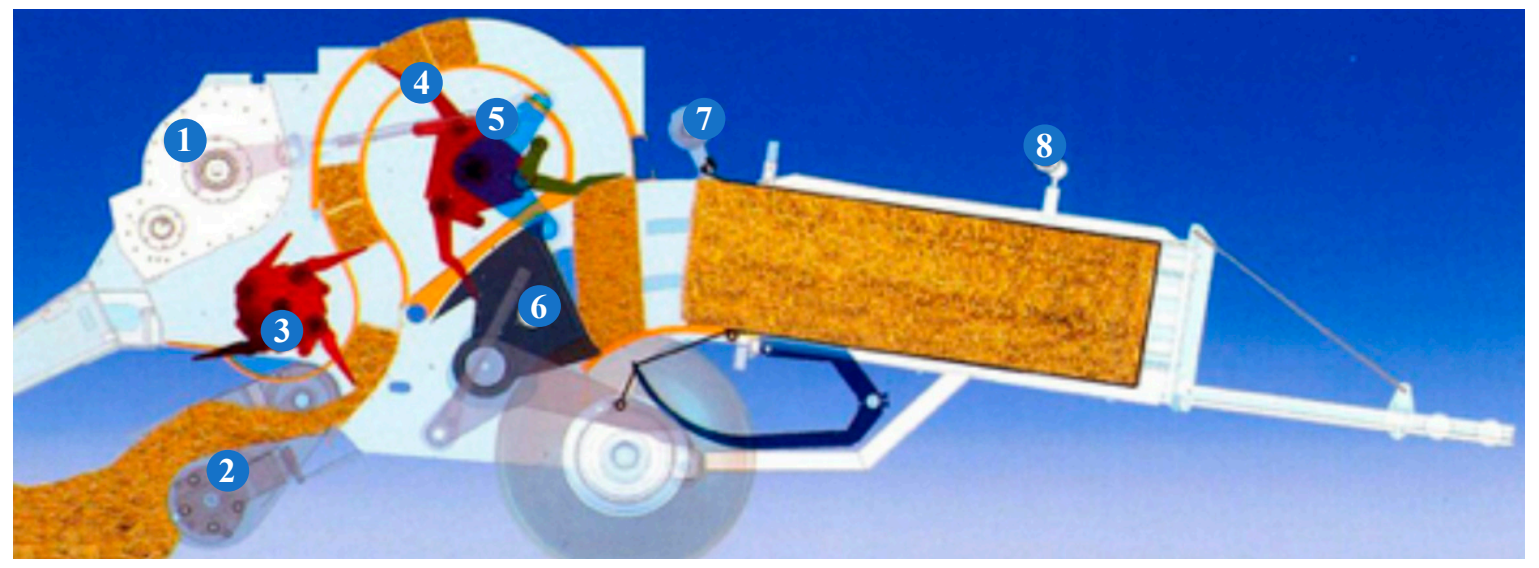

Figure 1. Working main outline of the large square baler HD 1270, manufactured by "Cicoria Square Bales".

The feeding system consists of two synchronized rotors which push the straw, hay and other by-products through a long channel of $3.3 \mathrm{~m}$, feeding from the top the compression chamber (Figure 2).

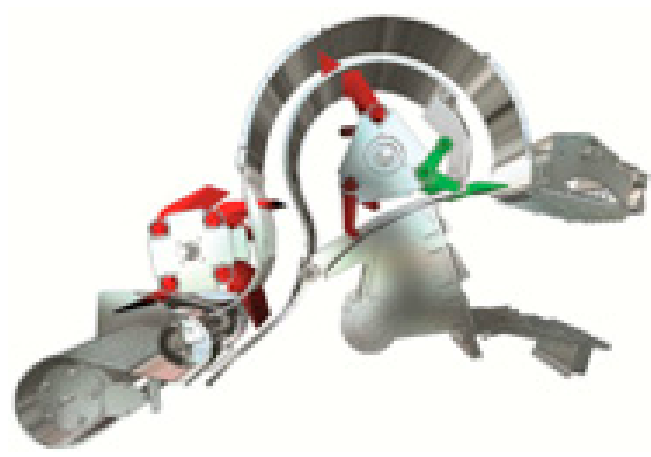

Figure 2. Extra-long channel equipped with two synchronized rotors (feeder rotor and compacting rotor) to remove dust and small stones from the product. 
In this way, it has improved the accumulation and expansion of the product ahead of dense compressing and binding of the solid bale. Furthermore, the top feeding reduces the possibility of loading stones and other harmful debris, leading to the production of higher quality forage. Finally, the binding system allows for single or double knotting and ensures top quality binding even at temperatures greater than $40{ }^{\circ} \mathrm{C}$ and straw and hay humidity of less than $3 \%$.

\section{Materials and Methods}

Experimental tests were carried out in order to evaluate the quantities of soil and impurities present in straw and hay bales built by the large square baler Cicoria HD 1270. In particular, the experimentation involved the collection of different hay and straw samples from prismatic bales made by both the Cicoria's machine and other two similar square balers, built by different manufacturers, hereinafter referred to as "competitor 1" and "competitor 2", respectively. The collected samples come from three different fields located near the head office of the Cicoria's machine manufacturer (Palazzo San Gervasio, Potenza district, Southern Italy) and were harvested at the same time on three consecutive working days. The essences of the samples were loietto (Lolium multiflorum L.), oats (Avena sativa L.) and vetch (Vicia sativa L.). In order to statistically assess the amount of impurities and soil inside the square bales, the samples were taken according to an experimental randomized block scheme. Therefore, three theses were considered for the straw, corresponding to the samples obtained from bales made respectively by: the Cicoria's machine (thesis 1), the "competitor 1" machine (thesis 2) and the "competitor 2" machine (thesis 3) (Table 1). In addition, two theses were considered for the hay, corresponding to the samples obtained from bales made respectively by: the Cicoria's machine (thesis 1) and from the "competitor 1" machine (thesis 2) (Table 1). Three repetitions were considered for each of the aforesaid theses.

Table 1. Theses analyzed for hay and straw, respectively.

\begin{tabular}{cccc}
\hline & Thesis 1 & Thesis 2 & Thesis 3 \\
\hline $\begin{array}{c}\text { straw } \\
\text { hay }\end{array}$ & Cicoria's machine & "competitor 1" machine & "competitor 2" machine \\
\hline
\end{tabular}

The collected samples were then analyzed in the laboratory of the Department of Agricultural and Environmental Science of the University of Bari Aldo Moro, according to the experimental procedure reported in Figure 3. In the first step, the samples underwent a drying process at $65^{\circ} \mathrm{C}$ for $3 \mathrm{~h}$ inside a forced air oven ARGOLAB model TCF 200 (Argolab-XS Instruments s.r.l. Industry, Carpi, Modena district, Italy). The main technical features of the forced air oven used were: usable volume $200 \mathrm{~L}$; homogeneity temperatures at $150{ }^{\circ} \mathrm{C} \pm 0.3{ }^{\circ} \mathrm{C}$; max temperature/resolution $+300^{\circ} \mathrm{C} / 0.1{ }^{\circ} \mathrm{C}$; supply voltage $230 \mathrm{~V}$ and nominal power $2400 \mathrm{~W}$. This process allowed both the elimination of humidity and the standardization of the initial conditions for all the samples considered.

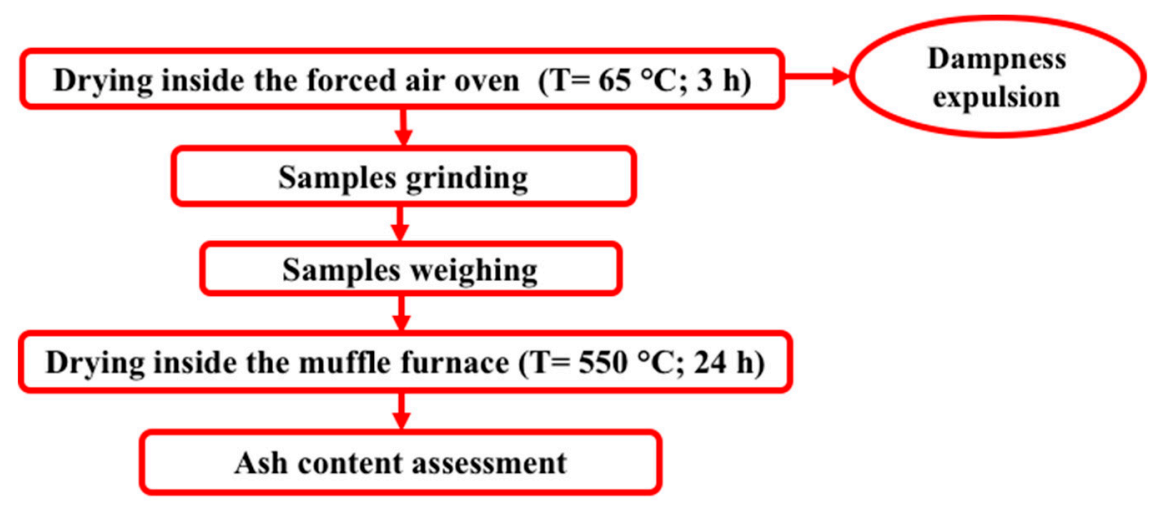

Figure 3. Flow chart showing hay and straw sample processing. 
The second step of the experimental procedure was to grind the samples using a cutting mill RETSCH model 5657 (Retsch Italia-Verder Scientific s.r.l. Industry, Torre Boldone, Bergamo district, Italy), in order to obtain a fineness of $2 \mathrm{~mm}$. The main technical characteristics of this device were: shaft angular speed (at a supply frequency rate of $50 \mathrm{~Hz}) 314 \mathrm{rad} \mathrm{s}^{-1}\left(3000 \mathrm{~min}^{-1}\right)$; final fineness $0.25-20 \mathrm{~mm}$; supply voltage $380 \mathrm{~V}$ and nominal power $1100 \mathrm{~W}$ (Figure 4a).

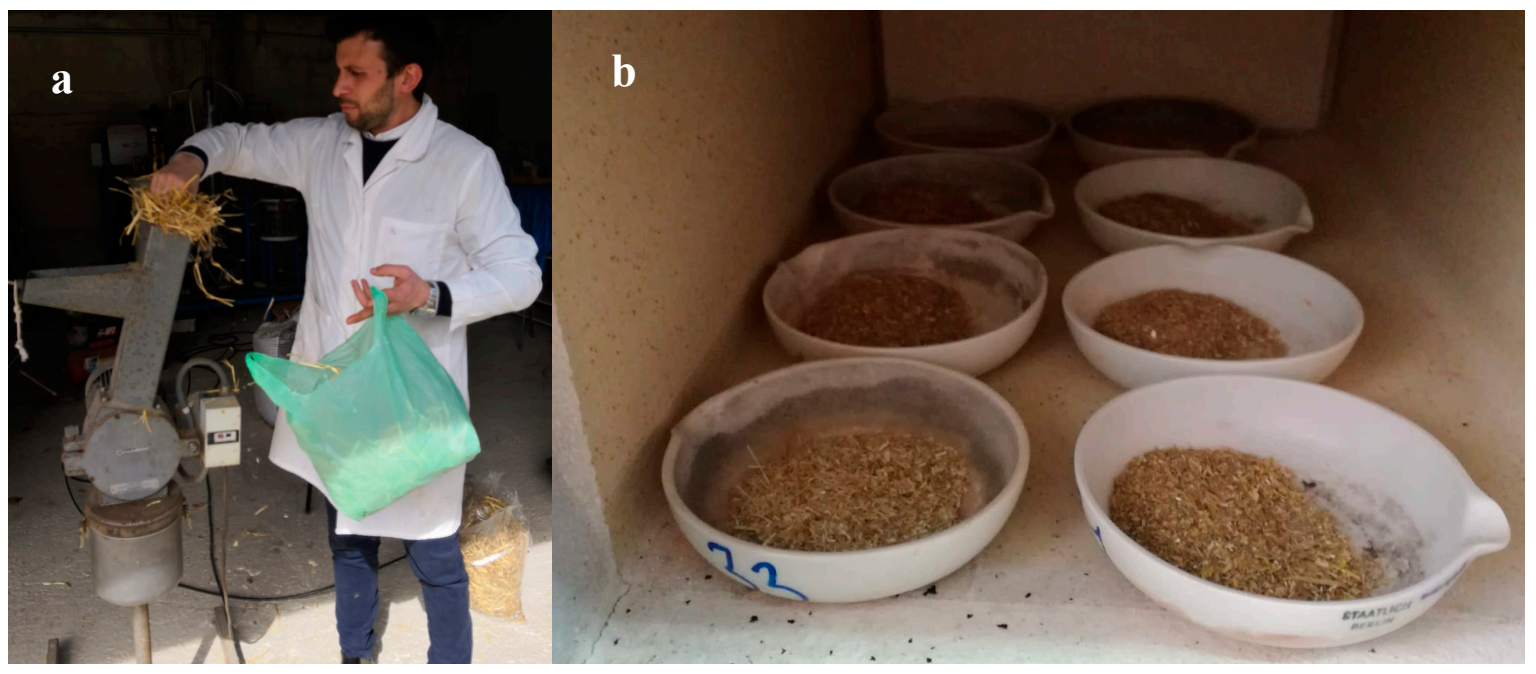

Figure 4. Hay and straw sample processing: (a) sample grinding; (b) cups with respective hay and straw contents placed inside the muffle furnace.

The third step was to weigh $2 \mathrm{~g}$ of each ground sample using the electronic analytical balance ABT model 220-5DM (KERN \& SOHN GmbH Industry, Balingen, Germany) having the following main technical characteristics: max capacity 220 g; readability $0.00001 \mathrm{~g}$. Each weighted sample was then placed in a cup suitable for heating in the furnace. Considering the theses and the repetitions, 15 cups were prepared. For the fourth step of the experimental procedure, all the cups, with their respective contents, were placed inside a muffle furnace Zetalab model ZA (Zetalab s.r.l. Industry, Padova district, Italy) to achieve a drying process at a temperature of $550{ }^{\circ} \mathrm{C}$ for $24 \mathrm{~h}$ in order to evaluate the ash content (Figure $4 \mathrm{~b}$ ). The main technical characteristics of the muffle furnace were: max temperature $1100{ }^{\circ} \mathrm{C}$; supply voltage $380 \mathrm{~V}$ and nominal power $3900 \mathrm{~W}$.

Finally, after this drying treatment, the contents of the cups were again weighed in order to assess the difference between the initial weight and the weight after the completion of drying process so that it was possible to calculate the ashes content percentage.

\section{Results and Discussion}

The data concerning the straw samples of the three theses for comparison were statistically analyzed through the variance analysis and the average values were compared using the "Duncan test" at a significance level of $0.05 \%$ [28]. The results highlight (Figure 5) a significant difference among the ashes percentages for the samples obtained from the square bales from, respectively, the Cicoria's machine (thesis 1) and the "competitor 1" (thesis 2) and "competitor 2" (thesis 3) machines, also taking into account that the difference between the ashes percentages for these last two theses was not significant. In particular, the analysis showed that the average value of impurities and soil present in the straw bales produced by the Cicoria's machine was equal to $7.79 \%$, which is $10 \%$ lower than the average value of the "competitor 1 " machine and $11.4 \%$ lower than the "competitor 2 " machine (Figure 5). 


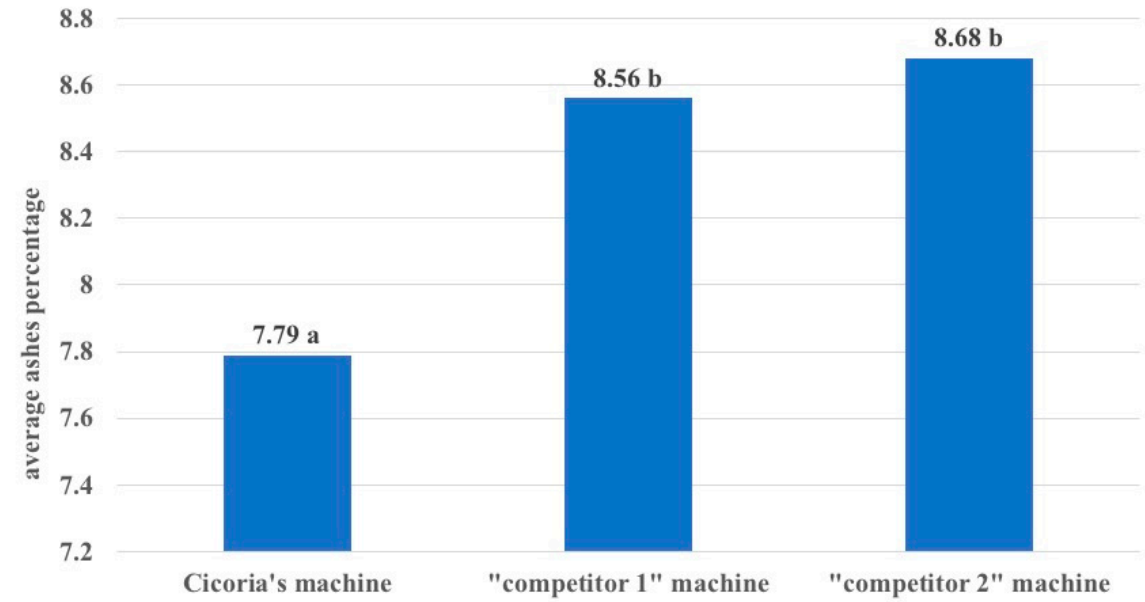

Figure 5. Variance analysis and Duncan Test at a significance level of $0.05 \%$ applied to data from the straw samples of the three comparison theses.

Furthermore, the data concerning the hay samples were statistically analyzed through the variance analysis, although the "Least Significant Difference" (LSD) test was used at a significance level of $0.05 \%$, as only two theses were available for comparison [28]. The results show a significant difference between the average ashes percentages (due to impurities and soil) concerning the samples obtained from the hay square bales from, respectively, the Cicoria's machine (thesis 1) and the "competitor 1" (thesis 2) machine (Figure 6). In particular, inside the forage bales built with the Cicoria's machine an ashes percentage of $6.41 \%$ was obtained which was $27.3 \%$ lower than the average percentage value found in the ashes of the bales of forage produced by the "competitor 1" machine.

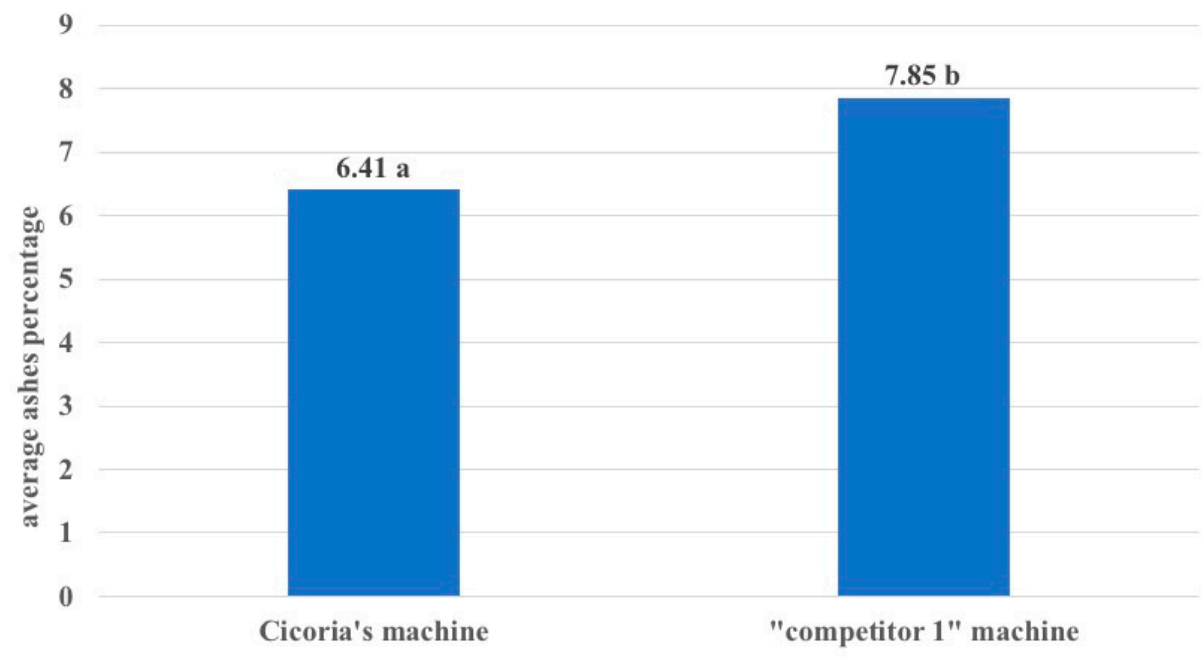

Figure 6. Variance analysis and "Least Significant Difference" test at a significance level of $0.05 \%$ applied to data from the forage samples of the two comparison theses.

\section{Conclusions}

The large square baler HD 1270 manufactured by "Cicoria Square Bales" is equipped with innovative technological systems which allow the machine to achieve remarkable performance. In particular, the compression device with the balancing piston, combined with the long channel through which the hay or straw travels, pushed by the synchronized rotors to feed from the top the compression chamber, considerably improves the effectiveness in producing square bales and reduces the energy requirements in comparison with other similar machines. The experimental tests carried out seem to confirm the benefits of these technical solutions. However, in order to better understand 
the reliability of the machine in lowering the amount of impurities and soil present in the square bales produced, further tests in different working conditions should be carried out in order to statistically evaluate the influence and mutual interaction of some of the operating parameters, such as the soil characteristics (structure and texture, humidity), the type of swath and the harvesting height from soil of the hay and straw.

Author Contributions: Conceptualization and Methodology, A.S.G. and S.P.; Formal Analysis, Investigation and data curation, A.S.G., F.S. and A.S.A.; Writing-Original Draft Preparation, A.S.G. and F.S.; Writing-Review \& Editing, A.S.A and F.S.; Supervision, S.P.

Conflicts of Interest: The authors declare no conflict of interest.

\section{References}

1. Pöllinger, A. Vergleich unterschiedlicher Heutrocknungsverfahren. In Gumpensteiner Bautagung; Bundesanstalt für alpenländische Landwirtschaft Gumpenstein: Irdning, Austria, 2003; pp. 63-68.

2. Van Soest, P.J.; Robertson, J.B. Analysis of forages and fibrous feeds. In Laboratory Manual for Animal Science 613; Cornell University: Ithaca, NY, USA, 1985; p. 18.

3. Shinners, K.J.; Huenink, B.M.; Muck, R.E.; Albrecht, K.A. Storage Characteristics of large round and square Alfalfa: Low moisture wrapped bales. Trans. ASABE 2009, 52, 401-407. [CrossRef]

4. Amours, L.D.; Savoie, P. Density profile of corn silage in bunker silos. CBE 2005, 47, 221-228.

5. Manetto, G.; Cerruto, E.; Pascuzzi, S.; Santoro, F. Improvements in citrus packing lines to reduce the mechanical damage to fruit. Chem. Eng. Trans. 2017, 58, 391-396. [CrossRef]

6. Maguire, S.M.; Godwin, R.J.; O'Dogherty, M.J.; Blackburn, K. A dynamic weighing system for determining individual square bale weights during harvesting. Biosyst. Eng. 2007, 98, 138-145. [CrossRef]

7. D'Alessandro, F.; Bianchi, F.; Baldinelli, G.; Rotili, A.; Schiavoni, S. Straw bale constructions: Laboratory, in field and numerical assessment of energy and environmental performance. J. Build. Eng. 2017, 11, 56-68. [CrossRef]

8. Maraldi, M.; Molari, L.; Molari, G.; Regazzi, N. Time-dependent mechanical properties of straw bales for use in construction. Biosyst. Eng. 2018, 172, 75-83. [CrossRef]

9. Maraldi, M.; Molari, L.; Regazzi, N.; Molari, G. Analysis of the parameters affecting the techanical behaviour of straw bales under compression. Biosyst. Eng. 2017, 160, 179-193. [CrossRef]

10. Sun, Y.; Buescher, W.; Lin, J.; Schulze Lammers, P.; Ross, F.; Maack, C.; Cheng, Q.; Sun, W. An improved penetrometer technique for determining bale density. Biosyst. Eng. 2010, 105, 273-277. [CrossRef]

11. Cazzato, E.; Laudadio, V.; Tufarelli, V. Effects of harvest period, nitrogen fertilization and mycorrhizal fungus inoculation on triticale (xTriticosecale Wittmack) forage yield and quality. Renew. Agric. Food Syst. 2012, 27, 278-286. [CrossRef]

12. Adler, A. Qualität von Futterkonserven und mikrobielle Kontamination. In 8. Alpenländisches Expertenforum; Bundesanstalt für alpenländische Landwirtschaft Gumpenstein: Irdning, Austria, 2002; pp. 17-26.

13. Li, M.; Sun, Y.; Cheng, Q.; Jungbluth, K.H.; Buescher, W.; Maack, C.; Cheng, H.; Wang, Z. Mapping oxygen-induced temperature patterns of round bale silage based on $3 \mathrm{D}$ stepwise-profiling measurement. Measurement 2016, 82, 115-122. [CrossRef]

14. Román, F.D.; Hensel, O. Numerical simulations and experimental measurements on the distribution of air and drying of round hay bales. Biosyst. Eng. 2014, 122, 1-15. [CrossRef]

15. Cazzato, E.; Tufarelli, V.; Laudadio, V.; Stellacci, A.M.; Selvaggi, M.; Leoni, B.; Troccoli, C. Forage yield and quality of emmer (Triticum dicoccum Schübler) and spelt (Triticum spelta L.) as affected by harvest period and nitrogen fertilization. Acta Agric. Scand. Sect. B Soil Plant Sci. 2013, 63, 571-578.

16. Wilkinson, J.M.; Davies, D.R. The aerobic stability of silage: Key findings and recent developments. Grass Forage Sci. 2013, 68, 1-19. [CrossRef]

17. Pascuzzi, S.; Cerruto, E.; Manetto, G. Foliar spray deposition in a "tendone" vineyard as affected by airflow rate, volume rate and vegetative development. Crop Prot. 2017, 91, 34-48. [CrossRef]

18. Pascuzzi, S.; Santoro, F. Exposure of farm workers to electromagnetic radiation from cellular network radio base stations situated on rural agricultural land. Int. J. Occup. Saf. Ergon. 2015, 21, 351-358. [CrossRef] [PubMed] 
19. Cerruto, E.; Manetto, G.; Santoro, F.; Pascuzzi, S. Operator Dermal Exposure to Pesticides in Tomato and Strawberry Greenhouses from Hand-Held Sprayers. Sustainability 2018, 10, 2273. [CrossRef]

20. Pascuzzi, S.; Blanco, I.; Anifantis, A.S.; Scarascia Mugnozza, G. Hazards assessment and technical actions due to the production of pressured hydrogen within a pilot photovoltaic-electrolyzer-fuel cell power system for agricultural equipment. J. Ag. Eng. 2016, 47, 88-93. [CrossRef]

21. Baldoin, C.; Balsari, P.; Cerruto, E.; Pascuzzi, S.; Raffaelli, M. Improvement in pesticide application on greenhouse crops: Results of a survey about greenhouse structures in Italy. Acta Hortc. 2008, 801, 609-614. [CrossRef]

22. Anifantis, A.S.; Colantoni, A.; Pascuzzi, S.; Santoro, F. Photovoltaic and Hydrogen Plant Integrated with a Gas Heat Pump for Greenhouse Heating: A Mathematical Study. Sustainability 2018, 10, 378. [CrossRef]

23. Pascuzzi, S.; Blanco, I.; Anifantis, A.S.; Scarascia Mugnozza, G. Electrolyzer Performance Analysis of an Integrated Hydrogen Power System for Greenhouse Heating. A Case Study. Sustainability 2016, 8, 629. [CrossRef]

24. Pascuzzi, S.; Santoro, F. Analysis of Possible Noise Reduction Arrangements inside Olive Oil Mills: A Case Study. Agriculture 2017, 7, 88. [CrossRef]

25. Santoro, F.; Anifantis, A.S.; Ruggiero, G.; Zavadsky, V.; Pascuzzi, S. Lightning Protection Systems Suitable for Stables: A Case Study. Agriculture 2019, 9, 72. [CrossRef]

26. Langer, T.H.; Ebbesen, M.K.; Kordestani, A. Experimental analysis of occupational whole-body vibration exposure of agricultural tractor with large square baler. Int. J. Ind. Ergon. 2015, 47, 79-83. [CrossRef]

27. Bell, B. Farm. Machinery, 5th ed.; Old Pond Publishing: Ipswich, UK, 2005.

28. Gomez, K.A.; Gomez, A.A. Statistical Procedures for Agricultural Research, 2nd ed.; Wiley-Interscience: New York, NY, USA, 1984; ISBN 978-0471870920.

(C) 2019 by the authors. Licensee MDPI, Basel, Switzerland. This article is an open access article distributed under the terms and conditions of the Creative Commons Attribution (CC BY) license (http://creativecommons.org/licenses/by/4.0/). 